\title{
EFFECT OF SOME HERBICIDES ON SORGHUM SEEDLING CHARACTERS, WEED CONTROL AND SEED BORNE FUNGI
}

\author{
KHAFFAGY, AZZA E. ${ }^{1}$, S.M. MOGHAZY ${ }^{2}$ and M.S. ABD RABBOH ${ }^{2}$ \\ 1. Weed Research Central Laboratory, ARC, Giza, Egypt. \\ 2. Plant pathology institute, ARC, Giza, Egypt.
}

(Manuscript received 15 June 2014)

\begin{abstract}
Two field experiments were conducted at Sakha Agriculture Research Station, Agriculture Research Center, Kafr El-sheikh Governorate, Egypt during 2012 and 2013 seasons to determine the effect of some herbicides on seedlings characters and its reflection on plant growth and yield of sorghum. Each experiment included seven treatments in a complete randomized block design. Results revealed that five herbicides i.e. acetochlor at $900 \mathrm{~g}$ a.i/fed (Vern $90 \% \mathrm{EC}$ ), acetochlor at $840 \mathrm{~g}$ a.i/fed (Harness $84 \% \mathrm{EC}$ ), pendimthalin at $773.5 \mathrm{~g}$ a.i./fed (Stomp Extra $45.5 \% \mathrm{CS}$ ), butralin at $1200 \mathrm{~g}$ a.i./fed (Amex $48 \% \mathrm{EC}$ ) and metribuzin at $210 \mathrm{~g}$ a.i./fed (Metribuzin El-Nasr 70\% WG) increased germination percentage and seedlings growth of sorghum. These herbicides gave satisfactory effect in controlling both annual broadleaf and grassy weeds and had wide spectrum for controlling weed species grown with sorghum plants at more than $80 \%$ which reflected on increasing plant growth and yield, and was superior than hand hoeing (twice) during the two growing seasons. Therefore, such herbicides can be applied in sorghum field. The above mentioned herbicides at 0,1000 and $2000 \mathrm{\mu g} \mathrm{ml}^{-1}$ were used to treat sorghum grains after harvest. The results showed also that acetochlor at 900 $\mathrm{g}$ a.i./fed (Vern 90\%), acetochlor at $840 \mathrm{~g}$ a.i./fed (Harness 84\%), pendimethalin at $773.5 \mathrm{~g}$ a.i./fed (Stomp Extra 45.5\%) at $2000 \mu \mathrm{g}$ $\mathrm{ml}^{-1}$ level, were very effective in inhibiting the growth of grain-born fungi.

Key word: Weeds, Sorghum bicolor, seed-borne fungi
\end{abstract}

\section{INTRODUCTION}

Sorghum is an important crop, used for food as grain; sorghum syrup or "sorghum molasses"; and fodder. In Egypt, sorghum is one of the most important summer cereals for both human and animal consumption, grown for grain and forage. The cultivated area is about 380000 feddans producing about 6.5 million ardab of grain yield in 2012 year $^{1 *}$. Damping off and seedling blight of sorghum caused by several soil borne fungi i.e Pythium sp., Fusarium moniliforme, Fusarium semitectum, Fusarium Alternaria alternate, Alternaria solani, Epicocum nigrum and Nigrospora

* Bulletin of the Agriculture Statistics, Economic Affairs Sector. Vol.2 Summer and Nilicrops. July 2010 Ministry of Agriculture and Land Reclamation 
oryzae are the most important fungal diseases in Egypt (Samar El-sayed 2014), Altman and Camppbell (1977); Pupavizas and Leuris (1979) reported that herbicides may affect pathogen growth, sporulation, propagules germination, inoculum density, survival in soil and competitive saprophytic ability. These effects could be brought about by several mechanisms, such as direct effects on the pathogen and virulence, on host susceptibility and on other competitive or inhibitory microorganisms. Hance (1980) indicated that the majority of field studies revealed that many herbicides decrease soil -borne diseases. There is a wide variety of physiological and biochemical effects which herbicides can have on crops at doses below those which are deference's to yield or health. The apparently minor effects may influence the crops susceptibility to disease. Cook and Hutter (1981), Shebayan (1982) and Govedarica et al (2001) reported that, herbicides affect soil microbes indirectly, through different mechanisms. Lynch (1983) showed that, herbicides derived from carbamic acid are decomposed microbiologically, chemically, and photochemically. Among the fungi affected by herbicides Rhizopus spp., Aspergillus spp., and Penicillium spp. and among the bacteria are Pseudomonas $s p$. and Bacillus $s p$. In general, herbicides mode of action depend on concentration, and chemical composition. Moreover, Lipsa et al (2010). found that, the populations of soil fungi and bacteria were affected by treatment with herbicide (S-metolachlor). Significant decreases in soil biological activity with all herbicide applied, and the increase of herbicide dose may kill some soil microorganisms. Ishaya et al. (2007) found that, pretilachl or+dimethametryne at $2.5 \mathrm{~kg}$ a.i./ha, cinosulfuron at $0.05 \mathrm{~kg}$ a.i./ha and piperophos + cinosulfuron at $1.5 \mathrm{~kg}$ a.i./ha effectively controlled weeds and increased crop vigour, plant height and grain yield of sorghum. Raghuvanshi et al. (1990) and layoke et al. (1990) showed that weeds reduced $14-54$ and $40-86 \%$ of sorghum forage yield and grain yield by $14-54 \%$ and $40-86 \%$ respectively. In Egypt, there is no official recommendation of herbicides for weeds in sorghum, therefore, the present investigation aims to find some suitable herbicides to control weeds in sorghum fields and to study their effects on grain-borne fungi.

\section{MATERIALS AND METHODS}

Two field experiments were conducted at Sakha Agricultural Research Station, Kafer El-Sheikh during 2012 and 2013 seasons. The aim of this investigation, is to study the effect of herbicides on some seedlings characters as well as grain yield of sorghum hybrid 888 (Sorghum bicolor, L. Moench), using six weed control treatments. Sorghum 
was sown on 15 and 10 June in the 2012 and 2013 seasons, respectively, and harvested on 20, September in 2012 and 2013 seasons.

The experimental design used was randomized complete block design, with four replicates. The plot area was $6.3 \mathrm{~m}^{2}$ ((3.0m length and $2.1 \mathrm{~m}$ width) and included three ridges with $70 \mathrm{~cm}$ distance. Each ridge contained 15 hill at $20 \mathrm{~cm}$ distance and 3 seeds/ hill. Seedlings were thinned to secure the required number of plants before the second irrigation. The weed control treatments used were as follows:

A. Acetochlor [2-chloro- $N$-(ethoxymethyl)- $N$-(2-ethyl-6-methylphenyl) acetamide], known commercially as Harness $84 \%$ EC, was applied at $840.0 \mathrm{~g}$ a.i./fed.

B. Acetochlor [2-chloro- $N$-(ethoxymethyl)- $N$-(2-ethyl-6-methylphenyl) acetamide], know commercially as Vern $90 \% \mathrm{EC}$, was applied at $900.0 \mathrm{~g}$ a.i./fed.

C. Pendimethalin[ $N$-(1-ethylpropyl)-3,4-dimethyl-2,6-dinitrobenzenamine], known commercially as Stomp Extra $45.5 \% \mathrm{CS}$, was applied at $773.5 \mathrm{~g}$ a.i./fed.

D. Butralin [4-(1,1-dimethylethyl)- $N$-(1-methylpropyl)-2,6-dinitrobenzenamine], known commercially as Amex 48\% EC, was applied at $1200.0 \mathrm{~g}$ a.i./fed.

E. Metribuzin [4-amino-6-tert-butyl-4,5-dihydro-3-methylthio-1,2,4-triazin-5-one;4amino-6-tert-butyl-3-methylthio-1,2,4-triazin-5(4H)-one], known commercially as Metribuzin El-Nasr 70\% WG, was applied at $210.0 \mathrm{~g}$ a.i./fed.

All herbicides were applied as surface spraying after sowing.

F. Hand weeding (twice) after at 15 and 30 days from sowing.

G. Untreated check.

Table (a). Chemical group and mode of action of the herbicides used according to Ashton and Crafts (1981).

\begin{tabular}{|l|c|l|}
\hline \multicolumn{1}{|c|}{ Herbicides } & Chemical group & \multicolumn{1}{|c|}{ Mode of action in plants } \\
\hline $\begin{array}{l}\text { Acetochlor (Vern 90\% EC) } \\
\text { Acetochlor (Harness 84\% EC) }\end{array}$ & Chloroacetamides & $\begin{array}{l}\text { meristem mitotic disruptors in root cell } \\
\text { division. }\end{array}$ \\
\hline $\begin{array}{l}\text { Pendimethalin (Stomp Extra 45.5\% CS) } \\
\text { Butralin (Amex 48 \% EC) }\end{array}$ & Dinitroanilines & $\begin{array}{l}\text { meristem shoot inhibitors in shoot cell } \\
\text { growth and division. }\end{array}$ \\
\hline Metribuzin (Metribuzin El-Nasr 70\% WG) & Triazines & $\begin{array}{l}\text { photosynthesis II inhibitors block the } \\
\text { hill reaction within light cannot be } \\
\text { converted to chemical energy. }\end{array}$ \\
\hline
\end{tabular}

The herbicides were sprayed by knapsack sprayer CP3 prepared in water volume of 200 liters per faddan immediately prior of irrigation. The preceding winter crop in the two seasons was barley. The cultural practices for sorghum were applied accordance to local recommendations. 
The collected data recorded were as follows:

A- Effect of herbicidal treatments on germination percentage and seedlings growth of sorghum under field conditions:

One week after planting, the germinated seeds was recorded and estimated as described by Gopinath et al. (1987) as follow:

I- Germination \% =

No. of emerged seedlings

$\mathrm{X} 100$

No. of planted seeds

II- Length ( $\mathrm{cm}$ ) and dry weight of shoot and root $(\mathrm{g}) / 15$ seedlings were also estimated.

III- Vigour index (VI) of seedlings was estimated according to the method adapted by Purushotham et al. (1996) as follow:

Vigor index $(\mathrm{VI})=$ (mean root length + mean shoot length) $\mathrm{X}$ percentage of seed germination.

\section{B - Dry weight of weeds $\left(\mathrm{g} / \mathrm{m}^{2}\right)$ :-}

Weeds were randomly hand pulled from one square meter of each plot after 45 and 75 days from sowing and separated into broadleaf and grassy.

Weight was determined as $\left(\mathrm{g} / \mathrm{m}^{2}\right)$ after drying in a forced draft oven at $70 \mathrm{C}^{\circ}$ for 48 hours.

Reduction percentage ( $\mathrm{R} \%$ ) in annual weeds, was calculated according Topps and Wain (1957): $\quad R \%=(A-B) / A X 100$

Where: $\quad A=$ dry weight of weeds in untreated plot.

$B=$ dry weight of weeds in treated plot.

\section{C-Weeds susceptibility to herbicides:}

The susceptibility of weeds species to herbicides was measured after 45 days from sowing depending on the reduction percentage of the dry weight of each species compared to the un-weeded check according to Frans and Talbert (1977) as: Susceptible (S) = > $90 \%$, Moderately susceptible (MS) $=80-89 \%$, Moderately tolerant $(\mathrm{MT})=60-79 \%$, and Toleran $(\mathrm{T})=<60 \%$.

Five broadleaf and two grassy weeds were evaluated.

\section{D - Growth characters and yield components:}

At harvest time:

1-Samples of ten plants were collected at random from the central ridges of each plot to assess the following: plant length $(\mathrm{cm})$; plant weight $(\mathrm{g})$ and leaf area index (LAI) .Leaves of the fresh samples of wheat plants were separated and used in leaf area determination. Leaf area was measured using leaf area meter (Model LI.3000 A).

2- Forage yield $\mathrm{kg} / \mathrm{plot}$ and grain yield $\mathrm{kg} / \mathrm{plot}$. were determined from each plot and was extrapolated to yield per Fadden. 


\section{E- Effect of the tested treatments on seed health:}

After harvest, samples $(1 / 2 \mathrm{~kg})$ of sorghum grain hybrid 888 (susceptible hybrid to seed rot diseases) were taken from each replicate and surface sterilized using $1 \%$ sodium hypochlorite solution for 3 minutes. It, washed several times in sterilized water, and blotted between two sterilized filter papers. One hundred seeds were treated by each tested herbicide for each concentration (1000 and $2000 \mu \mathrm{g} \mathrm{ml}^{-1}$ ). Twenty five grains were transferred in each of four $9 \mathrm{~cm}$ Petri dishes on moist filter paper and incubated at $27^{\circ} \pm 1 \mathrm{C}^{\circ}$ for 7 days [ISTA, 1999]. The development fungi was counted as the number of seeds contaminated with growth of each fungal / Petri dish according to Gopinath et al. (1987) and percentages were calculated.

\section{Statistical analysis:}

The obtained data were subjected to analysis of variance according to Gomez and Gomez (1984). Treatment means were compared by Duncan's Multiple Range Test (Duncan, 1955). All statistical analysis was performed using analysis of variance technique by means of MSTAT-C computer software package.

\section{RESULTS AND DISCUSSION}

\section{A: Effect of herbicidal treatments on seedling characters in sorghum:}

Data presented in Table (1) showed that all the tested herbicides significantly increased the germination \%, comparing with control treatment. Soil treatment with acetochlor at $900 \mathrm{~g}$ a.i./fed, acetochlor at $840 \mathrm{~g}$ a.i./fed, pendimethalin at $773.5 \mathrm{~g}$ a.i./fed were the most effective in increasing germination percent (96.0, 93.0 and $91.7 \%$ during 2012 and 94.0, 92.3 and $90.3 \%$ during 2013, respectively) as compared with control treatment which recorded 80.0 and 82.0 germination percentage during 2012 and 2013 growing seasons, respectively. Similar, findings were obtained by Govedarica et al (2001), who found that, herbicides affect soil microbes indirectly. Herbicides may be a source of nutrition for microbes, in this case, they significantly affect microbial growth and multiplication. However, herbicides also affect the microbes physiologically by changing their biosynthetic mechanism, by affecting protein biosynthesis, by affecting plant growth regulators and if they applied in high doses, they may kill microorganisms.

With regard to seedling growth characters (length, fresh and dry weight of shoot and root), soil herbicides treatment with acetochlor at $900 \mathrm{~g}$ a.i./fed, acetochlor at $840 \mathrm{~g}$ a.i./fed, pendimethalin at $773.5 \mathrm{~g}$ a.i./fed were the most effective and suitable way for producing healthy and strong seedling, because the soil treatment by them led to increase shoot and root length (the length of shoot and root were 31.67 and $13.83 \mathrm{~cm}$ with acetochlor at $840 \mathrm{~g}$ a.i./fed, 31.17 and $13.00 \mathrm{~cm}$ with pendimethalin at $773.5 \mathrm{~g}$ a.i./fed was 35.33 and $14.83 \mathrm{~cm}$ with acetochlor at $900 \mathrm{~g}$ a.i./fed, respectively during season 2012. Dry weight of shoot and root were 1.57 and 
$0.50 \mathrm{~g}$ with acetochlor at $840 \mathrm{~g}$ a.i./fed, 1.37 and $0.54 \mathrm{~g}$ with pendimethalin at 773.5 $\mathrm{g}$ a.i./fed and 2.74 and $0.78 \mathrm{~g}$ with acetochlor at $900 \mathrm{~g}$ a.i./fed, respectively during 2012 growing season. Seedling vigour index (VI) were 42.01, 40.04 and 47.99 with acetochlor at $840 \mathrm{~g}$ a.i./fed, pendimethalin at $773.5 \mathrm{~g}$ a.i./fed and acetochlor at $900 \mathrm{~g}$ a.i./fed, respectively, during season 2012. On the other hand, the soil treatment with butralin at $1200 \mathrm{~g}$ a.i./fed and metribuzin at $210 \mathrm{~g}$ a.i./fed, had low effect in increasing germination percentage and were also had low effect in enhancement of growth seedling characters as comparing with control treatment, during 2012 growing season. In the same line and recorded similar trends for the effect of soil treatment by tested herbicides on increasing of germination \% and also effect of them on enhancement of seedling growth characters, during 2013 growing season. Similar, results were obtained by Lipsa et al. (2010) in that, the population of soil fungi and bacteria were affected by treatment with the herbicide (S- metalochlor). The analysis of the total number of microorganisms in the sampling soils, before (the control soil) and after herbicide application, shown significant decreases of soil biological activity in all variants where herbicide was applied. The increase of herbicide dose may kill most soil microorganisms.

Table 1. Effect of some herbicides on germination \%, length, fresh and dry weight of shoot and root of sorghum seedling during 2012 and 2013 seasons.

\begin{tabular}{|c|c|c|c|c|c|c|}
\hline \multirow{4}{*}{ Treatments } & \multicolumn{6}{|c|}{2012 season } \\
\hline & \multirow{3}{*}{$\begin{array}{c}\text { Germination } \\
\% \\
\text { Seed } \\
\text { germination } \\
\%\end{array}$} & \multicolumn{5}{|c|}{ Seedling growth } \\
\hline & & \multicolumn{2}{|c|}{ Length $(\mathrm{cm})$} & \multicolumn{2}{|c|}{ Dry weight (g) } & \multirow{2}{*}{ VI } \\
\hline & & Shoot & Root & Shoot & Root & \\
\hline Acetochlor (840.0 g a.i./fed) & $93.00 \mathrm{~b}$ & $31.67 \mathrm{~b}$ & $13.83 a b$ & $1.57 c$ & $0.50 \mathrm{~b}$ & $42.01 b$ \\
\hline Acetochlor (900.0 g a.i./fed) & $96.00 \mathrm{a}$ & $35.33 a$ & $14.83 a$ & $2.74 a$ & $0.78 \mathrm{a}$ & $47.99 a$ \\
\hline Pendimethalin (773.5 g a.i./fed) & $91.67 \mathrm{~b}$ & $31.17 \mathrm{~b}$ & $13.00 \mathrm{~b}$ & $1.37 \mathrm{c}$ & $0.50 \mathrm{~b}$ & $40.04 b$ \\
\hline Butralin (1200.0 g a.i./fed) & $87.33 \mathrm{c}$ & $29.00 \mathrm{c}$ & $11.17 \mathrm{c}$ & $0.81 d$ & $0.42 b c$ & $34.23 c$ \\
\hline Metribuzin (210.0 g a.i./fed) & $87.33 \mathrm{c}$ & $27.33 d$ & $9.83 d$ & $0.75 d$ & $0.38 \mathrm{c}$ & $32.45 \mathrm{c}$ \\
\hline Hand hoeing twice & $82.33 \mathrm{~d}$ & $29.33 c$ & $11.17 \mathrm{c}$ & $2.10 \mathrm{~b}$ & $0.46 b c$ & $33.48 \mathrm{c}$ \\
\hline \multirow[t]{2}{*}{ Untreaded check } & $80.00 \mathrm{~d}$ & $28.99 c$ & $11.00 c$ & $2.00 \mathrm{~b}$ & $0.44 c$ & $32.5 c$ \\
\hline & \multicolumn{6}{|c|}{2013 season } \\
\hline Acetochlor (840.0 g a.i./fed) & $92.33 \mathrm{~b}$ & $30.33 b$ & $13.17 \mathrm{~b}$ & $1.52 \mathrm{c}$ & $0.47 \mathrm{~b}$ & $39.89 b$ \\
\hline Acetochlor (900.0 g a.i./fed) & $94.00 \mathrm{a}$ & $34.33 a$ & $14.50 a$ & $2.41 a$ & $0.71 a$ & $45.63 a$ \\
\hline Pendimethalin (773.5 g a.i./fed) & $90.33 \mathrm{~b}$ & $29.67 b$ & $12.17 \mathrm{c}$ & $1.33 d$ & $0.43 \mathrm{bc}$ & $37.58 \mathrm{c}$ \\
\hline Butralin (1200.0 g a.i./fed) & $87 . .67 \mathrm{c}$ & $28.00 c$ & $10.50 d$ & $0.75 \mathrm{e}$ & $0.38 \mathrm{~cd}$ & $33.55 d$ \\
\hline Metribuzin (210.0 g a.i./fed) & $86.00 c$ & $27.00 \mathrm{c}$ & $9.50 \mathrm{e}$ & $0.71 \mathrm{e}$ & $0.35 d$ & $31.22 f$ \\
\hline Hand hoeing twice & $82.67 \mathrm{~d}$ & $28.00 \mathrm{~b}$ & $10.83 d$ & $1.87 \mathrm{~b}$ & $0.42 b c$ & $31.67 e$ \\
\hline Untreaded check & $82.00 \mathrm{~d}$ & $27.99 c$ & 10.00de & $1.83 \mathrm{~b}$ & $0.40 \mathrm{bc}$ & $31.5 \mathrm{e}$ \\
\hline
\end{tabular}

Means followed by the same alphabetical letters were not statistically significant according to Duncan;s multiple range test. 


\section{B -Effect of weed control treatments:}

\section{I - On weeds:-}

Table (2) showed that the infestation rates with the annual broadleaf and grassy weeds (dry weight $\mathrm{g} / \mathrm{m}^{2}$ ) were 2.64 ton and 4.55 ton/fed. with total 7.19 of total weeds respectively after 75 days from sowing in 2012 season, while it were 3.77 ton and 2.60 ton with total weeds by 6.37 ton/fed., respectively, in 2013 season. In general, all weed control treatments gave significant reduction on the two categories of the annual weeds (dry weight $\mathrm{g} / \mathrm{m}^{2}$ ). However, the herbicidal treatments were superior than hand hoeing treatment compared to untreated control. That was true in two assessments and both seasons. acetochlor at $900 \mathrm{~g}$ a.i./fed (Vern 90\%), acetochlor at $840 \mathrm{~g}$ a.i./fed (Harness 84\%), pendimethalin at $773.5 \mathrm{~g}$ a.i./fed (Stomp Extra $45.5 \%$ ) and at butralin at $1200 \mathrm{~g}$ a.i./fed (Amex 48\%), metribuzin at $210 \mathrm{~g}$ a.i./fed (Metribuzin El-Nasr 70\%) followed by hand hoeing twice gave the significant reduction on broadleaf weeds by $87,82,80.5,75,74.3$ and $73.1 \%$, respectively; in after 45 days from sowing survey and 90.8, 88.1, 83.3, 79, 77.3 and 74.3\%, repetitively; in after 75 days from sowing survey in first season. While, the previous respective treatments gave the redaction percentage on the grassy weeds by 86.6 , $85.1,82.8,77.1,76.1$ and $74.5 \%$, respectively, after 45 days from sowing survey; and $90,87,85.4,80.8,75.5$ and $72.4 \%$, respectively, after 75 days from sowing survey. The same trend was observed on reduction two categories of the annual weeds in the second season. acetochlor at $900 \mathrm{~g}$ a.i./fed, acetochlor at $840 \mathrm{~g}$ a.i./fed, pendimethalin at $773.5 \mathrm{~g}$ a.i./fed and at butralin at $1200 \mathrm{~g}$ a.i./fed, metribuzin at 210 $\mathrm{g}$ a.i./fed and hand hoeing twice treatments gave reduction percentage on the broadleaf weeds by $85.1,82.5,79.2,73.3,72$ and $71.7 \%$, respectively, in $1^{\text {st }}$ after 45 days from sowing survey, $90.9,89,87,80.4,77.8$ and $77.2 \%$, respectively, in $2^{\text {nd }}$ after 75 days from sowing survey. Meanwhile; the reduction percentage for grassy weeds by the previous respective treatments reached to $87.8,84.6,83,79.7,76.8$ and $73.7 \%$, respectively, in $1^{\text {st }}$ survey, and $89.5,87.3,84.2,79,74.7$ and $74.4 \%$, respectively, in $2^{\text {nd }}$ after 75 days from sowing survey. 
Table 2. Effect of treatments on dry weight of broadleaf, grasses and total annual weeds $\left(\mathrm{g} / \mathrm{m}^{2)}\right.$ after 45 and 75 days from sowing in 2012 and 2013 seasons.

\begin{tabular}{|c|c|c|c|c|c|c|}
\hline \multirow{3}{*}{ Weed control treatments } & \multicolumn{6}{|c|}{2012 season } \\
\hline & \multicolumn{3}{|c|}{45 days after sowing } & \multicolumn{3}{|c|}{75 days after sowing } \\
\hline & $\begin{array}{c}\text { Broadleaf } \\
\mathrm{g} / \mathrm{m}^{2}\end{array}$ & $\begin{array}{c}\text { Grasses } \\
\mathrm{g} / \mathrm{m}^{2}\end{array}$ & $\begin{array}{l}\text { Total } \\
\mathrm{g} / \mathrm{m}^{2}\end{array}$ & $\begin{array}{c}\text { Broadleaf } \\
\mathrm{g} / \mathrm{m}^{2}\end{array}$ & $\begin{array}{c}\text { Grasses } \\
\mathrm{g} / \mathrm{m}^{2}\end{array}$ & $\begin{array}{l}\text { Total } \\
\mathrm{g} / \mathrm{m}^{2}\end{array}$ \\
\hline Acetochlor (840.0 g a.i./fed) & $64.3 c$ & $38.8 \mathrm{c}$ & $98.00 \mathrm{~d}$ & 74.8 bc & $141.3 \mathrm{~cd}$ & $216.0 \mathrm{~cd}$ \\
\hline Acetochlor (900.0 g a.i./fed) & $42.8 \mathrm{~d}$ & $35.0 \mathrm{c}$ & $77.75 \mathrm{~d}$ & $57.8 \mathrm{c}$ & $108.3 \mathrm{~d}$ & $166.0 \mathrm{~d}$ \\
\hline Pendimethalin (773.5 g a.i./fed) & $64.3 \mathrm{c}$ & 44.8 bc & $109.00 \mathrm{~cd}$ & $105.0 \mathrm{bc}$ & $157.8 \mathrm{bcd}$ & $262.8 \mathrm{~cd}$ \\
\hline Butralin (1200.0 g a.i./fed) & $81.8 \mathrm{bc}$ & $59.5 \mathrm{~b}$ & $141.25 \mathrm{bc}$ & $131.8 \mathrm{bc}$ & $208.0 \mathrm{bcd}$ & $339.8 b c$ \\
\hline Metribuzin (210.0 g a.i./fed) & $84.5 b$ & $62.3 \mathrm{~b}$ & $146.75 b$ & $142.5 \mathrm{bc}$ & $265.0 \mathrm{bc}$ & $407.5 b$ \\
\hline Hand hoeing twice & $88.5 \mathrm{~b}$ & $64.0 \mathrm{~b}$ & $154.75 b$ & $161.0 \mathrm{~b}$ & $298.3 b$ & 459. $3 \mathrm{~b}$ \\
\hline \multirow[t]{2}{*}{ Untreaded check } & $316.8 \mathrm{a}$ & $260.3 \mathrm{a}$ & $589.50 \mathrm{a}$ & $627.5 \mathrm{a}$ & $1083 \mathrm{a}$ & $1710 \mathrm{a}$ \\
\hline & \multicolumn{6}{|c|}{2013 season } \\
\hline Acetochlor (840.0 g a.i./fed) & $36.8 \mathrm{c}$ & $26.8 \mathrm{~cd}$ & 63.5 de & $98.3 \mathrm{~b}$ & $78.8 \mathrm{c}$ & $177.0 \mathrm{~d}$ \\
\hline Acetochlor (900.0 g a.i./fed) & $31.3 \mathrm{c}$ & $21.3 \mathrm{~d}$ & $52.5 \mathrm{e}$ & $81.8 \mathrm{~b}$ & $65.3 c$ & $147.0 \mathrm{~d}$ \\
\hline Pendimethalin (773.5 g a.i./fed) & $43.7 \mathrm{bc}$ & $29.5 \mathrm{~cd}$ & 73.3 cde & $108.8 \mathrm{~b}$ & $98.3 \mathrm{bc}$ & $214.5 \mathrm{~cd}$ \\
\hline Butralin (1200.0 g a.i./fed) & $56.0 \mathrm{~b}$ & $35.3 \mathrm{bcd}$ & $91.3 \mathrm{bcd}$ & $176.3 b$ & $130.0 \mathrm{bc}$ & $306.8 \mathrm{bc}$ \\
\hline Metribuzin (210.0 g a.i./fed) & $58.8 \mathrm{~b}$ & $40.3 \mathrm{bc}$ & $99.0 \mathrm{bc}$ & $198.8 \mathrm{~b}$ & $157.0 \mathrm{~b}$ & $335.8 \mathrm{~b}$ \\
\hline Hand hoeing twice & $59.5 \mathrm{~b}$ & $45.8 \mathrm{~b}$ & $105.3 b$ & $204.3 b$ & $159.0 \mathrm{~b}$ & $363.3 \mathrm{~b}$ \\
\hline Untreaded check & $210.0 \mathrm{a}$ & $173.8 \mathrm{a}$ & $383.8 \mathrm{a}$ & $897.0 \mathrm{a}$ & $620.0 \mathrm{a}$ & 1517 a \\
\hline
\end{tabular}

Means followed by the same alphabetical letters were not statistically significant according to Duncan;s multiple range test.

As for the decreasing dry weight of the total weeds, it was noticed that the herbicidal treatments as well as hand hoeing were significantly effective and identical the result obtained on each individual weeds class without change in arrange in both seasons.

Weed control treatments depressed the total dry weight weeds which could be arranged in a descending order as follows: acetochlor at $900 \mathrm{~g}$ a.ilfed, acetochlor at $840 \mathrm{~g}$ a.ilfed, pendimthalin at $773.5 \mathrm{~g}$ a.i.|fed, butralin at $1200 \mathrm{~g}$ a.i. ffed and metribuzin at $210 \mathrm{~g}$ a.i. ffed and hand hoeing twice (73.7\%) treatments at after 45 days from sowing, and $90.3,87.4,84.6,80.1,76.2$ and $73.1 \%$, respectively, at after 75 days from sowing, in the first season; and whilst, the reduction percentage by the previous respective treatments were $86.3,83.5,80.9,76.2,74,2$ and $72.6 \%$, at after 45 days from sowing, and 90.3, 88.3, 85.9, 79.8, 76.5 and $76.1 \%$, respectively, at after 75 days from sowing, in the second season. Similar results were obtained by Mahelle and Seth (1992) who found that applying pre-emergence herbicides decreased dry weight of weeds in sorghum field by $43-75 \%$.

\section{C - Weed species susceptibility to herbicides:}

The susceptibility scores of seven weed species to six herbicides according to the scale used by Frans and Talbert (1977) was measured depending on the reduction \% of the dry weight of each species in $\mathrm{g} / \mathrm{m}^{2}$ of any herbicide compared with untreated 
check was measured as mentioned in Table (3), that through 2012 and 2013 seasons, Corchorus olitorius, Xanthium strumarium, Amaranthus album, Portulaca olerocea, and Ammania aegyptiaca as annual broadleaf and Echionchloa colona and Dinebra retroflexa, as annual grassy weeds were susceptible (S) and moderate susceptible (MS) to acetochlor at $900.0 \mathrm{~g}$ a.i./fed. and acetochlor $840.0 \mathrm{~g}$ a.i./fed ranged between $86-97 \%$. The other herbicides such as pendimethalin at $773.5 \mathrm{~g}$ a.i./fed, butralin at $1200.0 \mathrm{~g}$ a.i./fed. and metribuzin at $210.0 \mathrm{~g}$ a.i./fed. gave the moderate susceptible response (MS) to the previous weeds species meaning that the 5 herbicides had wide spectrum of weed control.

Table 3. Susceptibility score of seven weed species to used herbicidal weeds after 45 days from application during 2012 and 2013 summer seasons.

\begin{tabular}{|c|c|c|c|c|c|c|c|}
\hline \multirow{2}{*}{ Characteristic } & \multicolumn{7}{|c|}{2012 season } \\
\hline & \multicolumn{7}{|c|}{ Controlling $\%$ \& weeds species susceptibility to herbicides } \\
\hline Weed species & \multicolumn{5}{|c|}{ Species of an annual broadleaf weeds } & \multicolumn{2}{|c|}{$\begin{array}{l}\text { Species of an annual } \\
\text { grassy weeds }\end{array}$} \\
\hline Herbicides & $\begin{array}{l}\text { Corchorus } \\
\text { olitorius }\end{array}$ & $\begin{array}{l}\text { Xanthium } \\
\text { strumarium }\end{array}$ & $\begin{array}{l}\text { Portulaca } \\
\text { olerocea }\end{array}$ & $\begin{array}{l}\text { Ammania } \\
\text { aegyptiaca }\end{array}$ & $\begin{array}{c}\text { Amaranthus } \\
\text { album }\end{array}$ & $\begin{array}{l}\text { Echionchloa } \\
\text { colona }\end{array}$ & $\begin{array}{l}\text { Dinebra } \\
\text { retroflexa }\end{array}$ \\
\hline Acetochlor (840.0 g a.i./fed) & $94(S)$ & $86((\mathrm{MS})$ & $90(\mathrm{~S})$ & $91(\mathrm{~S})$ & 89 (MS) & $90(\mathrm{~S})$ & $91(\mathrm{~S})$ \\
\hline Acetochlor (900.0 g a.i./fed) & $97(S)$ & $91(\mathrm{~S})$ & $96(S)$ & $91(\mathrm{~S})$ & $91(\mathrm{~S})$ & $91(\mathrm{~S})$ & $91(\mathrm{~S})$ \\
\hline Pendimethalin (773.5 g a.i./fed) & 89 (MS) & $82(\mathrm{MS})$ & 87 (MS) & 89 (MS) & 88 (MS) & 86 (MS) & 89 (MS) \\
\hline Butralin (1200.0 g a.i./fed) & 84 (MS) & $81(\mathrm{MS})$ & $82(\mathrm{MS})$ & 87 (MS) & 87 (MS) & 81 (MS) & 88 (MS) \\
\hline Metribuzin (210.0 g a.i./fed) & 80 (MS) & $81(\mathrm{MS})$ & 80 (MS) & 81 (MS) & 84 (MS) & 81 (MS) & 81 (MS) \\
\hline & \multicolumn{7}{|c|}{2013 season } \\
\hline Acetochlor (840.0 g a.i./fed) & $94(S)$ & 87 (MS) & $96(S)$ & $95(\mathrm{~S})$ & $88 \mathrm{MS}$ & $92 \mathrm{~S}$ & $92 \mathrm{~S}$ \\
\hline Acetochlor (900.0 g a.i./fed) & $97(S)$ & $91(\mathrm{~S})$ & $96(S)$ & $95(\mathrm{~S})$ & $90 \mathrm{~S}$ & $92 \mathrm{~S}$ & $93 \mathrm{~S}$ \\
\hline Pendimethalin (773.5 g a.i./fed) & 89 (MS) & 89 (MS) & 87 (MS) & 89 (MS) & 86 MS & $88 \mathrm{MS}$ & 89 MS \\
\hline Butralin (1200.0 g a.i./fed) & $84(\mathrm{MS})$ & 85 (MS) & 86 (MS) & 86 (MS) & $84 \mathrm{MS}$ & $82 \mathrm{MS}$ & $88 \mathrm{MS}$ \\
\hline Metribuzin (210.0 g a.i./fed) & 81 (MS) & 81 (MS) & 84 (MS) & 81 (MS) & 83 MS & $80 \mathrm{MS}$ & 81 MS \\
\hline
\end{tabular}

Susceptible

(S) $=>90 \%$.

Moderately tolerant $\quad(\mathrm{MT})=60-79 \%$.

Moderately susceptible (MS) $=80-89 \%$

Tolerant

$(T)=<60 \%$ 


\section{D- Effect of weed control treatments on growth characteristics and yield of sorghum:}

It can be seen in table (4) that all herbicides as well as hand hoeing treatments favorably affected growth characteristics and yield of sorghum, with increasing significant effect except with plant height $(\mathrm{cm})$. Also, their values were higher when the weed control treatments were more efficient. That was true in both seasons. Weed control treatments, however significantly affected the plant weight $(\mathrm{g})$ in the both seasons. The increasing values of plant weight $(\mathrm{g})$ was obtained by acetochlor at $900 \mathrm{~g}$ a.i. (fed with 164.1 and 242, respectively., acetochlor at $840 \mathrm{~g}$ a.i. Ifed with 96.9 and 183.1 , pendimethalin at $773.5 \mathrm{~g}$ a.i. Ifed by 85.5 and 158.1 ; butralin at $1200 \mathrm{~g}$ a.i./fed by 59.2 and 91.5 metribuzin at $210 \mathrm{~g}$ a.i./fed with 52.8 and 105.7; followed by hand hoeing twice 48.7 and 91, respectively; in the both season. Acetochlor at $900 \mathrm{~g}$ a.i./fed gave increasing value for LAI by 6.4 and 8.4; acetochlor at $840 \mathrm{~g}$ a.i./fed with 5.4 and 5.9; pendimethalin at $773.5 \mathrm{~g}$ a.i./fed by 5.1 and 4.6; butralin at $1200 \mathrm{~g}$ a.i./fed by 3.6 and 3.4; metribuzin at $210 \mathrm{~g}$ a.i./fed with 2.1 and 2.9; and hand hoeing twice 1.7 and 2.7 ; respectively.

With regard to forage yield (ton/fed) and grain yield (ardab/fed) in $1^{\text {st }}$ season, the highest increasing values were obtained by acetochlor at $900 \mathrm{~g}$ a.i./fed with $3.7 \mathrm{t} / \mathrm{fed}$ and $3.3 \mathrm{ardab} / \mathrm{fed}$, respectively; acetochlor at $840 \mathrm{~g}$ a.i./fed with $3 \mathrm{t} / \mathrm{fed}$ and 2.6 ardab/fed; pendimethalin at $773.5 \mathrm{~g}$ a.i./fed by $2.6 \mathrm{t} / \mathrm{fed}$ and $2 \mathrm{ardab} / \mathrm{fed}$; butralin at $1200 \mathrm{~g}$ a.i./fed by $1.3 \mathrm{t} / \mathrm{fed}$ and $1.2 \mathrm{ardab} / \mathrm{fed}$; metribuzin at $210 \mathrm{~g}$ a.i./fed with 1.6 t/fed and 1.3 ardab/fed; and hand hoeing twice 1.2 t/fed and 1.2 ardab/fed; respectively.

In the 2013, acetochlor at $900 \mathrm{~g}$ a.i./fed gave increasing values for forage and grain yield by $4.1 \mathrm{t} /$ fed and 5.6 ardab/fed, respectively; acetochlor at $840 \mathrm{~g}$ a.i./fed with 3.5 $\mathrm{t} /$ fed and $3.3 \mathrm{ardab} / \mathrm{fed}$; pendimethalin at $773.5 \mathrm{~g}$ a.i./fed by $2.2 \mathrm{t} / \mathrm{fed}$ and 3.1 ardab/fed; butralin at $1200 \mathrm{~g}$ a.i./fed by $2 \mathrm{t} /$ fed and $1.8 \mathrm{ardab} / \mathrm{fed}$; metribuzin at 210 $\mathrm{g}$ a.i./fed with $1.5 \mathrm{t} /$ fed and $2.2 \mathrm{ardab} /$ fed; and hand hoeing twice $1.2 \mathrm{t} /$ fed and 2.2 ardab/fed; respectively. The increases in forage and grain yield are attributed to the increases in plant weight and leaf area index (LAI). This was attributed to the decrease of weed / sorghum competition. Raghuvanshi et al. (1990) and layoke et al. (1990) showed that weeds reduced $14-54$ and $40-86 \%$ of sorghum forage yield or dry matter and the reduction in grain yield reached $85 \%$ in the presence of weeds competition. Ismail (2003) indicated that plant height was not significantly affected by weed control treatments in both seasons. 
Table 4. Effect of weed control treatments on growth characteristic and yield of sorghum in 2012 and 2013 seasons.

\begin{tabular}{|c|c|c|c|c|c|c|c|c|c|c|}
\hline \multirow[b]{2}{*}{ Herbicides } & \multicolumn{5}{|c|}{2012 season } & \multicolumn{5}{|c|}{2013 season } \\
\hline & $\begin{array}{l}\text { Plant height } \\
\text { (cm) }\end{array}$ & $\begin{array}{c}\text { Plant } \\
\text { weight } \\
(\mathrm{g})\end{array}$ & LAI & $\begin{array}{c}\text { Forage yield } \\
\text { ton/fed }\end{array}$ & $\begin{array}{l}\text { Grain yield } \\
\text { ardab/fed. }\end{array}$ & $\begin{array}{c}\text { Plant height } \\
\text { (cm) }\end{array}$ & $\begin{array}{c}\text { Plant weight } \\
\text { (g) }\end{array}$ & LAI & $\begin{array}{l}\text { Forage } \\
\text { yield } \\
\text { ton/fed }\end{array}$ & $\begin{array}{l}\text { Grain yield } \\
\text { ardab/fed. }\end{array}$ \\
\hline Acetochlor (840.0 g a.i. /fed) & $142.8 \mathrm{a}$ & 331.4ab & $11.9 a b$ & $8.2 \mathrm{a}$ & $11.9 \mathrm{a}$ & $155.5 a$ & $410.0 \mathrm{ab}$ & $10.7 a b$ & $9.3 a$ & $10.7 \mathrm{a}$ \\
\hline & $148.3 a$ & $398.6 a$ & $12.6 a$ & $8.9 \mathrm{a}$ & $12.6 \mathrm{a}$ & $165.7 a$ & $468.9 a$ & $12.3 a$ & $9.9 a$ & $12.3 \mathrm{a}$ \\
\hline $\begin{array}{l}\text { Pendimethalin (//3.5 g } \\
\text { a.i./fed) }\end{array}$ & $144.7 a$ & $320.0 a b$ & $11.6 a b$ & $7.8 \mathrm{ab}$ & $11.3 a b$ & $145.7 a$ & $385.0 \mathrm{ab}$ & $9.8 \mathrm{~b}$ & $8.0 \mathrm{ab}$ & $9.8 \mathrm{ab}$ \\
\hline Butralin (1200.0 g a.i./fed) & $145.7 a$ & $293.7 \mathrm{~b}$ & $10.5 \mathrm{~b}$ & $6.5 \mathrm{~b}$ & $10.5 b c$ & $154.9 a$ & $318.4 \mathrm{~b}$ & $8.9 \mathrm{~b}$ & $7.8 \mathrm{~b}$ & $8.5 \mathrm{~b}$ \\
\hline Metribuzin (210.0 g a.i./fed) & $143.9 a$ & $287.3 \mathrm{bc}$ & $9.3 b$ & $6,8 \mathrm{~b}$ & $10.6 \mathrm{bc}$ & $155.7 a$ & $332.6 \mathrm{bc}$ & $8.7 b c$ & $7.3 \mathrm{~b}$ & $8.9 \mathrm{~b}$ \\
\hline Hand hoeing twice & $147.8 \mathrm{a}$ & $283.2 \mathrm{c}$ & $9.0 \mathrm{c}$ & $6.4 \mathrm{~b}$ & $10.5 \mathrm{bc}$ & $153.6 a$ & $317.9 \mathrm{c}$ & $8.5 b c$ & $7.0 \mathrm{bc}$ & $8.9 \mathrm{~b}$ \\
\hline Untreaded check & $140.5 a$ & $234.5 d$ & $7.7 \mathrm{e}$ & $5.2 \mathrm{c}$ & $9.3 \mathrm{c}$ & $156.6 a$ & $226.9 \mathrm{~d}$ & $6.7 \mathrm{c}$ & $5.8 \mathrm{c}$ & $6.7 \mathrm{c}$ \\
\hline
\end{tabular}

Means followed by the same alphabetical letters were not statistically significant according to Duncan's multiple range test. 
Table 5. Effect of herbicides on the \% of emerging fungal species from sorghum grains (\% grains growing fungal growth).

\begin{tabular}{|c|c|c|c|c|c|c|c|c|c|c|c|c|}
\hline Herbicides & $\begin{array}{c}\text { Concentration } \\
\mu \mathrm{gll}^{-1}\end{array}$ & $\begin{array}{l}\text { Fusarium } \\
\text { moniliforme }\end{array}$ & $\begin{array}{c}\text { Fusarium } \\
\text { semitectum }\end{array}$ & $\begin{array}{l}\text { Fusarium } \\
\text { oxysporum }\end{array}$ & $\begin{array}{c}\text { Curvulavia } \\
\text { lunata }\end{array}$ & $\begin{array}{c}\text { Aspergillus } \\
\text { niger }\end{array}$ & $\begin{array}{c}\text { Aspergillus } \\
\text { flavus }\end{array}$ & $\begin{array}{c}\text { Penicilium } \\
s p .\end{array}$ & $\begin{array}{l}\text { Alternaria } \\
\text { alternata }\end{array}$ & $\begin{array}{c}\text { Alternaria } \\
\text { solani }\end{array}$ & $\begin{array}{c}\text { Epicocum } \\
\text { nigrum }\end{array}$ & $\begin{array}{l}\text { Nigrospor } \\
\text { a oryzae }\end{array}$ \\
\hline $\begin{array}{c}\text { Untreaded } \\
\text { (control) }\end{array}$ & 0 & $15.33 \mathrm{a}$ & $5.00 \mathrm{a}$ & $4.67 \mathrm{a}$ & $7.33 \mathrm{a}$ & $6.67 \mathrm{a}$ & $5.33 a$ & $3.33 \mathrm{a}$ & 6.67 a & $6.00 \mathrm{a}$ & $4.33 a$ & $3.00 \mathrm{a}$ \\
\hline $\begin{array}{l}\text { Acetochlor } \\
\text { (Harness 84\%) }\end{array}$ & $\begin{array}{l}1000 \\
2000\end{array}$ & $\begin{array}{l}13.7 \mathrm{~cd} \\
6.67 \mathrm{e}\end{array}$ & $\begin{array}{l}4.33 a \\
2.00 b\end{array}$ & $\begin{array}{l}3.67 \mathrm{a} \\
1.33 \mathrm{~b}\end{array}$ & $\begin{array}{l}4.33 c \\
2,33 d\end{array}$ & $\begin{array}{l}4.00 \mathrm{c} \\
1.67 \mathrm{~d}\end{array}$ & $\begin{array}{c}3.67 b c \\
1.67 c\end{array}$ & $\begin{array}{l}2.67 b \\
1.33 c\end{array}$ & $\begin{array}{l}4.33 \mathrm{~cd} \\
1.67 \mathrm{e}\end{array}$ & $\begin{array}{l}4.33 \mathrm{~cd} \\
2.00 \mathrm{e}\end{array}$ & $\begin{array}{l}2.67 \mathrm{c} \\
1.33 \mathrm{c}\end{array}$ & $\begin{array}{l}1.33 b \\
0.00 c\end{array}$ \\
\hline $\begin{array}{l}\text { Acetochlor } \\
\text { (Vern 90\%) }\end{array}$ & $\begin{array}{l}1000 \\
2000\end{array}$ & $\begin{array}{l}13.0 \mathrm{~d} \\
5.33 \mathrm{f}\end{array}$ & $\begin{array}{l}4.00 \mathrm{a} \\
1.33 \mathrm{c}\end{array}$ & $\begin{array}{l}3.67 \mathrm{a} \\
1.00 \mathrm{c}\end{array}$ & $\begin{array}{l}4.67 \mathrm{bc} \\
2.00 \mathrm{~d}\end{array}$ & $\begin{array}{l}3.67 \mathrm{~cd} \\
1.67 \mathrm{~d}\end{array}$ & $\begin{array}{c}3.33 \mathrm{bc} \\
1.67 \mathrm{c}\end{array}$ & $\begin{array}{c}2.33 \mathrm{cb} \\
1.00 \mathrm{c}\end{array}$ & $\begin{array}{l}4.00 \mathrm{~d} \\
1.33 \mathrm{e}\end{array}$ & $\begin{array}{l}3.67 \mathrm{~d} \\
1.67 \mathrm{e}\end{array}$ & $\begin{array}{l}2.00 \mathrm{c} \\
1.00 \mathrm{c}\end{array}$ & $\begin{array}{l}1.00 \mathrm{~b} \\
0.00 \mathrm{c}\end{array}$ \\
\hline Pendimethalin & $\begin{array}{l}1000 \\
2000 \\
\end{array}$ & $\begin{array}{l}14.0 \mathrm{bc} \\
7.33 \mathrm{e}\end{array}$ & $\begin{array}{l}4.33 \mathrm{a} \\
2.00 \mathrm{~b} \\
\end{array}$ & $\begin{array}{c}4.00 \mathrm{ab} \\
1.33 \mathrm{~b}\end{array}$ & $\begin{array}{l}4.67 \mathrm{bc} \\
2.33 \mathrm{~d}\end{array}$ & $\begin{array}{l}4.33 \mathrm{bc} \\
2.00 \mathrm{~d}\end{array}$ & $\begin{array}{l}4.33 \mathrm{~b} \\
2.00 \mathrm{c}\end{array}$ & $\begin{array}{l}3.67 \mathrm{a} \\
1.67 \mathrm{bc}\end{array}$ & $\begin{array}{l}4.67 b c \\
2.33 b c\end{array}$ & $\begin{array}{l}4.33 \mathrm{~cd} \\
2.67 \mathrm{~cd}\end{array}$ & $\begin{array}{c}3.33 a b \\
2.00 c \\
\end{array}$ & $\begin{array}{l}1.33 \mathrm{~b} \\
0.00 \mathrm{c}\end{array}$ \\
\hline Butralin & $\begin{array}{l}1000 \\
2000 \\
\end{array}$ & $\begin{array}{l}14.7 \mathrm{ab} \\
14.3 \mathrm{ab} \\
\end{array}$ & $\begin{array}{l}5.00 \mathrm{a} \\
4.33 \mathrm{a} \\
\end{array}$ & $\begin{array}{l}4.33 a \\
3.67 a \\
\end{array}$ & $\begin{array}{l}5.00 \mathrm{~b} \\
4.33 \mathrm{bc}\end{array}$ & $\begin{array}{l}4.33 b c \\
4.33 b c\end{array}$ & $\begin{array}{l}4.67 b \\
4.67 b \\
\end{array}$ & $\begin{array}{l}3.33 a \\
2.67 b \\
\end{array}$ & $\begin{array}{l}5.67 \mathrm{~b} \\
5.33 \mathrm{cb} \\
\end{array}$ & $\begin{array}{l}4.67 \mathrm{~cd} \\
4.33 \mathrm{~cd} \\
\end{array}$ & $\begin{array}{l}4.00 a b \\
3.00 b \\
\end{array}$ & $\begin{array}{r}3.00 \mathrm{a} \\
2.00 \mathrm{ab} \\
\end{array}$ \\
\hline Metribuzin & $\begin{array}{l}1000 \\
2000\end{array}$ & $\begin{array}{r}15.0 \mathrm{ab} \\
14.3 \mathrm{abc}\end{array}$ & $\begin{array}{l}4.67 \mathrm{a} \\
4.00 \mathrm{a}\end{array}$ & $\begin{array}{l}4.33 a \\
4.00 a\end{array}$ & $\begin{array}{l}5.67 b \\
5.67 b\end{array}$ & $\begin{array}{l}5.67 \mathrm{~b} \\
5.67 \mathrm{~b}\end{array}$ & $\begin{array}{l}4.67 b \\
4.00 \mathrm{bc}\end{array}$ & $\begin{array}{c}3.33 \mathrm{a} \\
3.00 \mathrm{ab}\end{array}$ & $\begin{array}{l}5.67 b \\
5.67 b\end{array}$ & $\begin{array}{l}5.67 \mathrm{ab} \\
5.33 \mathrm{abc}\end{array}$ & $\begin{array}{l}4.00 \mathrm{ab} \\
3.67 \mathrm{ab}\end{array}$ & $\begin{array}{l}3.00 \mathrm{a} \\
2.00 \mathrm{ab}\end{array}$ \\
\hline
\end{tabular}

Means followed by the same alphabetical letters were not statistically significant according to Duncan;s multiple range 


\section{E- Effect of the tested treatments on seed health:}

Data in Table (5) indicated that, herbicidal treatments of sorghum grains at $1000 \mu \mathrm{g}$ $\mathrm{ml}-1$ was not so effective in reducing the frequency of fungi emerging from grains. With exception of treatments with butralin and metribuzin, tested herbicides, at 2000 $\mu \mathrm{gl}^{-1}$ excreted an aberrance inhibitive effect on the developing fungi which was significantly reduced. Aspergillus flavus and $A$. niger were apparently inhibited, which is important, since these fungi are potentially capable of producing mycotoxins. It could be summarized that metribuzin and butralin were not effective in reducing the growth of almost all fungi. Other herbicides were inhibitive to fungal growth particularly at the $2000 \mathrm{\mu g} \mathrm{ml}^{-1}$ concentration. Moreover, ,Aspegillus flavus and $A$. niger were apparently inhibited by the high concentration. This is important because these fungi are potentially capable of producing toxins.

The conclusion from the above results suggested that Acetochlor at $900 \mathrm{~g} \mathrm{a.i} / \mathrm{fed}$, Acetochlor at $840 \mathrm{~g}$ a.i/fed and Pendimthalin at $773.5 \mathrm{~g}$ a.i./fed decreased dry weight of weeds, soil- born fungi and increased the germination percent on sorghum comparing with control treatment, that is may be due to kill of most soil borne fungi and can be advised for weed control in sorghum without any phytotoxicity on sorghum growth.

\section{REFERENCES}

1. Altman, J. and Campbell. C.L. 1977. Effect of herbicides on plant diseases. Annual, Revi. of Phytopathol, 15, 361-385.

2. Ashton, F.M. and Crafts, A.S. 1981. Mode of Action of Herbicides. Wiley- Inter Science Publication John Wiley \& Sons Second Edition.

3. Cook, A. M. and Hutter, A. 1981. S-triazines as nitrogen sources for bacteria. Agri. and Food Chemist $29:$ 1135-1143.

4. Duncan, D.B. 1955. Multiple range and multiple F. tests. Biometrcs, 11: 1-42

5. Frans, R.E. and R. Talbert. 1977. Design of field experminent and the measurement and analysis of plant response. Res. Methods in Weed Sci. Soc. Field. South. USA, Aburn, Alabama.

6. Gomez, K.A. and Gomez, A.A. 1984. Statistical Procedures for Agricultural Research. 2nd ed. Johnn Wiley Sons, New York, USA.

7. Gopinath, A.; Shethy, H. and Prakash, H. S. 1987. Colonization of Fusarium species in sorghum seeds and their significance. Indian Phytopath. 40 (2): 181185.

8. Govedarica, M.; Milosevic, N. and Konstantinovic, B. 2001. Utica J dimetenanida I metalahora na mikorbioloska svojstva zemljista pod spcernom repom. V. Jugoslovenske Savetovaje o Zastiti bilja, Zlatibor (12): 3-8. 
9. Hance, R.J. 1980. Interaction between herbicides and soil. Effects on soil microflora (Greaves, M.P. and Malkones, H.P. Eds) chapter pp 223-253. Academic press. Asubsidiary of Harcourt Brace Jovanovich. Publishers.

10. Ishaya, D.B., Dadari S.A., Shebayan J.A.Y. 2007. Evaluation of herbicides for weed control in sorghum (Sorghum bicolor) in Nigeria. Crop Protection, 26 (11) : 1697-1701.

11. Ismail, A.E.A. 2003. Studies on weed control in sorghum crop. Ph.D. Thesis, Fac. of Agric., Minia Univ.

12. I.S.T.A. 1999. International rules for seed testing association. Seed Sci. and Technol 27, 155-165.

13. Lagoke, S.T.O., Shebayan, J.A.Y., Adeosun, J.O., Iwafor, E.N.O., Olukosi, J., Emechebe, A., Zaria, N., Adeoti, A., Onyibe, J., and Chobe, S. 1990. Survey of Striga control methods in maize, sorghum and cowpea in the Nigerian savanna. Unpublished Paper Presented at the Pan African Striga Control Network Conference, Held at IITA-Ibadan, Nigeria, pp. 1-65.

14. Lipsa, F.D.; VIfa, E.; Chiriac, I.P. and Ceroi, I.G. 2010. Effect of herbicide Smetolachlor on soil microorganisms. Lucrari Stiintifice -Seria Agronomie 53 ( 2).

15. Lynch, J. M. 1983. Microorganisms and enzymes in the soil. In : Soil Biotechnology, Microbiological Factors in Crop Productivity, Blackwell Sci. Publ., London, 185.

16. Mahelle, S.S and Seth J. 1992. Interaction between nitrogen application and weedicides in sorghum (Sorghum bicolour). Indian J. of Agron. , 37 (3): 583585.

17. Raghuvanshi, R. K. S.;. Thakur R. S;. Unat R and Nema M. J. 1990. Crop technology for optimum grain production in sorghum - wheat sequence under resource restrains. Indian J. of Agron.. 35 (3): 246-250.

18. Pupavizas, G.C. and Leuris J. A. 1979. Side effects of pesticides on soil -borne plant pathogens. In Soil- borne Plant Pathogens (B.Schippers and W.Gam, Eds.), pp. 483-505. Academic Press, London and New York.

19. Purushotham, S.P., Kechav Patkar, L. and Shekara Shetty, H. 1996. Storage fungi and their influence on rice seed quality. Indian Phytopath.49 (2): 152-156.

20. Shebayan, J.A.Y., 1982. Differential response of Guinea corn varieties to herbicides in Nigeria. M.Sc. Thesis, Depart. of Agron. Ahmadu Bello University, Zaria, pp. 1-7.

21. Samar, S.A. El-Sayed 2014. Integrated management of seed rots and seedling blight disease of forage and grain sorghum in Egypt. M.Sc.Thesis, Fac. Agric. Mansoura Univ. Egypt.

22. Topps, J. H. and Wain R.L. 1957. Investigation of fungi toxicity of 3- and 5-alkyl salicylinlide and para- chloroaniline. Ann. Appli. Biol. 5 (3): 506-511. 
تأثير بعض مبيدات الحشائش على نمو البادرات و الفطريات المحمولة بالتربة و مكافحة الحشائش فى محصول الأرة الرفيعة

عزة السيد خفاجي 'و سليمان محمد المغازى ؟ مدحت سعيد عبد ربه؟

$$
\begin{aligned}
& 1 \text { - الهعمل المركزي لبحوث الحشائش - مركز البحوث الزراعية - الجبزة - مصر }
\end{aligned}
$$

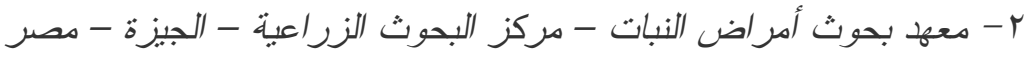

أجريت تجربتان حقليتان في المزرعة البحثية بمحطة البحوث الزر اعية بسخا محافظة كفر

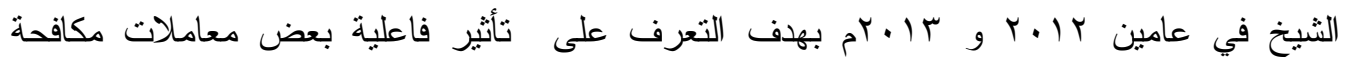
الحشائش على نسبة الإنبات و انعكاس ذلك على صفات النى النمو و إنتاجية محصول الذرة الرفيعة. وكانت

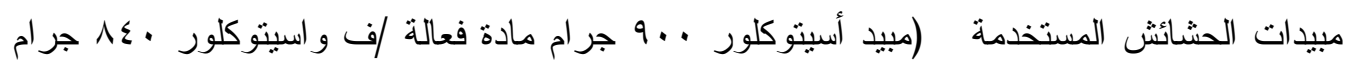

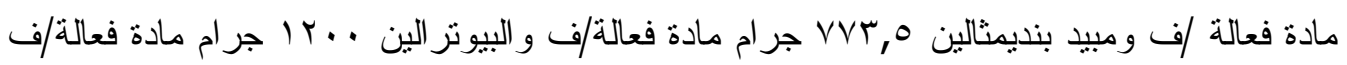

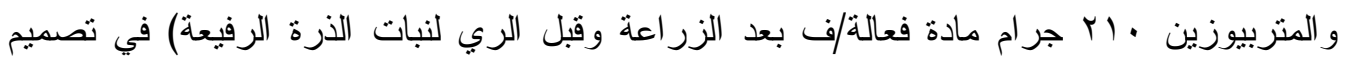

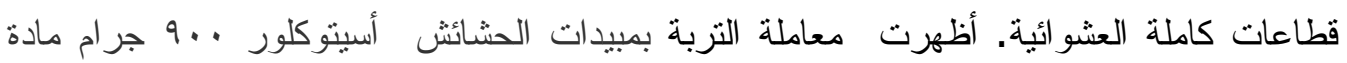

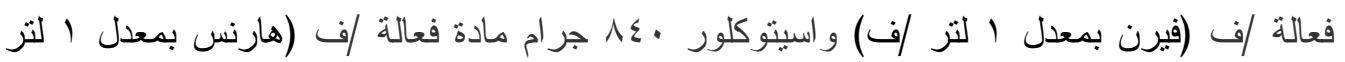

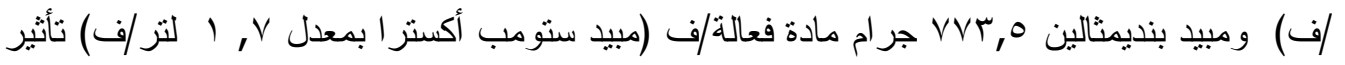
كبير في الحد من موت البادرات قبل وبعد الانبثاق وبالتالي زيادة نسبة الإنبات للحبوب المنزر عة لإنة و إنتاج بادرات سليمة وكذللك أدت لزيادة الطول و الوزن الجاف للريشة و الجذير للبادرات الناتجة

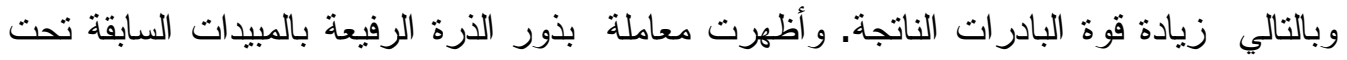

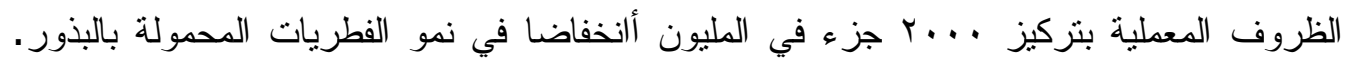

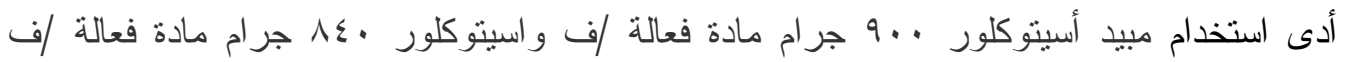
و مبيد بنديمثالين O, VVT جرام مادة فعالة/ف إلى نقص كبير في الوزن الجاف للحشائش عريضة

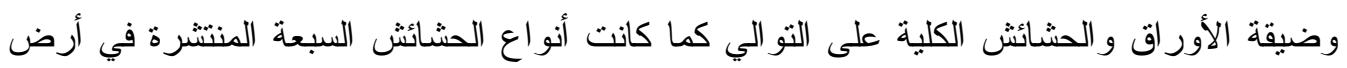
التجارب حساسة إلى هذه المبيدات لذلك يمكن التوصية باستخدام مبيدات أسيتوكلور . .9 جرام ام مادة

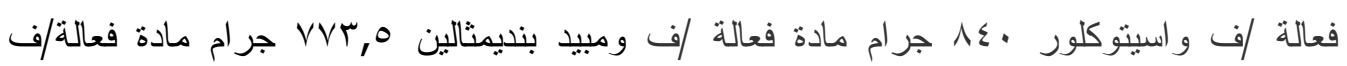
لمكافحة الحشائش الحولية في محصول الذرة الرفيعة كلا موسمي الزر اعة وذللك مقارنة بمعاملة الكنترول. كما أحدثت هذه المبيدات السابقة زيادة كبيرة في محصول العلف و محصول الحبوب التبه وتقوقت إنتاجيتها على باقي المعاملات ويرجع ذلك لتحسين صفات الإنبات وقوة البادرا ت الناتجة 